\title{
Pressure Drop - Flow Relationships in Cigarette Filter Rods and Tobacco Columns*
}

\author{
by C. H. Keith \\ Celanese Fibers Company, Charlotte, North Carolina, U.S.A.
}

\section{INTRODUCTION}

In the measurement or theoretical calculation of the pressure drop of cigarette filters and tobacco columns, the assumption is usually made that the flow in the article is laminar or viscous. With this assumption, pressure drop will be directly proportional to the volumetric flow rate and the length of the specimen. In other words, it obeys Darcy's Law of viscous flow. Fordyce et al. (1) found this relationship to hold for filter rods. However, Meyer-Abich (2), Strydom and Otto (3) and Palmade (4) found that tobacco columns had a somewhat non-linear pressure drop - flow relationship indicating a degree of inertial flow. Conversely, Baker (5) indicates that Darcy's Law holds to a good approximation in the tobacco columns used in his work. To resolve this question, and to determine the relative pressure drop contributions of laminar flow, inertial flow and the effects of channeling air into and out of the rods, a series of measurements were undertaken on filter rods, tobacco columns and multicapillary pressure drop standards. A further object of this work was to determine whether gas expansion effects, thermal changes and holder effects were contributing to the observed pressure drops. Although this work parallels Palmade's (4) thorough study of tobacco columns and reaches many of the same conclusions independently, it extends the flow analysis to filter rods and pressure drop standards and considers other possible contributions to pressure drop.

\section{APPARATUS}

Since it was necessary to have accurate and simultaneous measurements of pressure drop and flow rate, a simple apparatus was devised to provide the necessary data. As shown in Figure 1, this consists of an oil displacement burette, a manometer and a rubber sleeve encapsulating holder. The flow is provided by pumping mineral oil into or out of the burette by means of two Zenith gear

\footnotetext{
" Presented at the 33rd Tobacco Chemists' Research Conference, Lexington, Kentudky, 1979, and the Coresta Tednology Group Meeting, Bristol, U.K., 1979.

Received: 26th February 1981 - accepted: 8th September 1981.
}

pumps driven in tandem by a reversible variable speed motor. Since the oil can be pumped in either direction it is possible to obtain a pressure drop under pressure conditions, where air is being forced through the rod or under the normal vacuum condition, where air is being sucked into the rod from the surrounding atmosphere. The flow rate is determined by measuring the time that it takes for the oil meniscus to travel between two graduation marks representing a volume of $1000 \mathrm{ml}$. It was found that the manometer reading pressure drop did not appreciably change during the filling or emptying of the burette, which indicates a constant flow rate through the pumps. Valves are provided to connect the appropriate

Figure 1. Pressure drop and flow measurement.

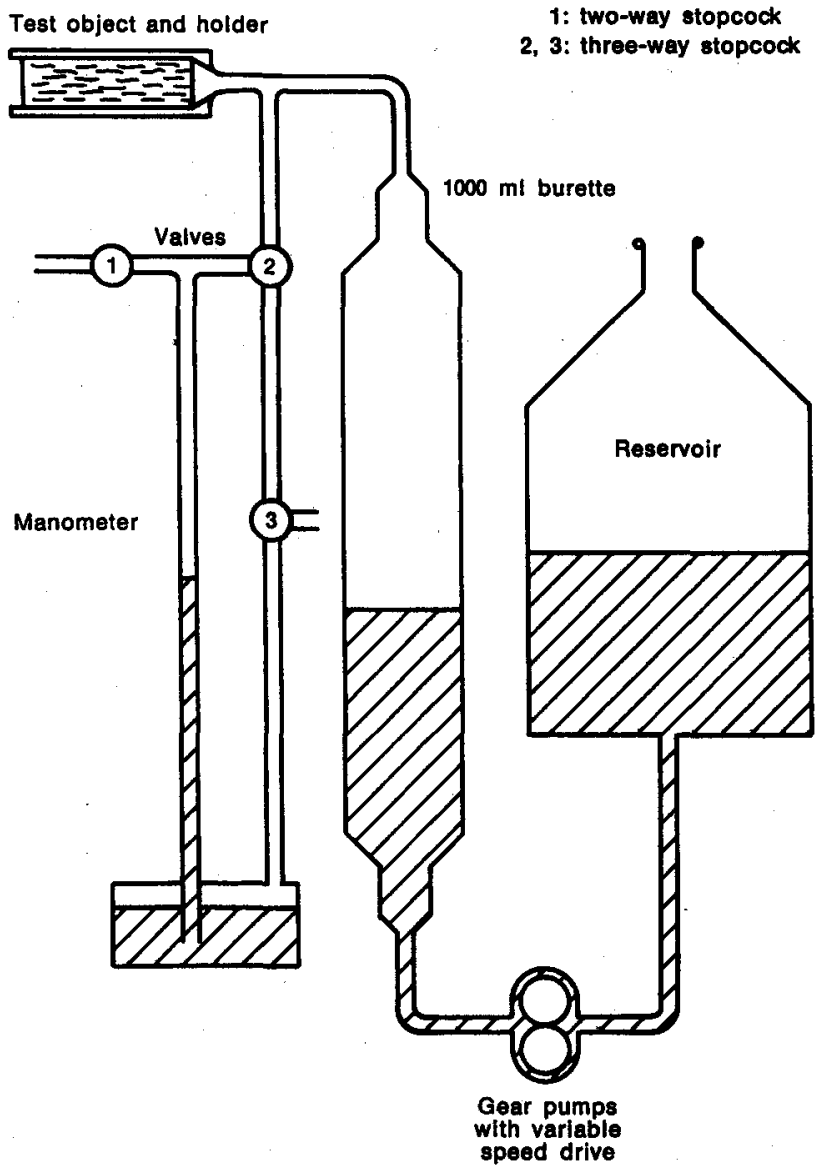


end of the manometer to the flow apparatus and to leave the opposite end open to the atmosphere during the pressure or vacuum measurements.

The rod holder consisted of a latex sleeve encapsulator of Celanese design. The article being measured was fully inserted into the encapsulator to eliminate air leakage through the wrapper. In addition, a wrapping of cellophane tape was generally applied to the filter rods and tobacco columns to further insure against wrapper leakage and to provide additional rigidity to obviate collapse of the rods at higher flow rates.

\section{RESULTS AND DISCUSSION}

With this equipment, pressure drops were measured at 6 to 7 flow rates ranging from 2.5 to $22 \mathrm{ml} / \mathrm{s}$. Cellulose acetate filter rods of a normal $3.3 \mathrm{Y} / 44000$ tow and a coarse $25 \mathrm{R} / 50000$ tow were investigated as were tobacco columns consisting of an American-type blend cut at 32 cuts per inch (cut width: $\approx 0.8 \mathrm{~mm}$ ). All items had a normal circumference of $24.8 \mathrm{~mm}$ and the lengths ranged from 10 to $12 \mathrm{~mm}$ for the filter rods and from 25 to $85 \mathrm{~mm}$ for the tobacco columns. In addition a series of 10 tube glass multicapillary standards similar to those described by Keith and Corbin (6) of $120 \mathrm{~mm}$ length and nominal pressure drops between 100 and $643 \mathrm{~mm}$ were tested.

In Table 1, data are presented for a $120 \mathrm{~mm} 3.3$ denier per filament (dpf) acetate tow filter under pressure and vacuum flow conditions. If we look at pressure drop as a function of the measured flow rate, we find that the pressure drops are different depending on whether a pressure or vacuum system is employed. For example, at a common measured flow rate of $22.4 \mathrm{ml} / \mathrm{s}$, the pressure measurements gives $487 \mathrm{~mm}$ and the vacuum $467 \mathrm{~mm}$ pressure drop. The reason for this is quite simple, we are not measuring the same flow rate in the two types of measurement. In the pressure case, the measured flow rate is that entering the rod, while in the vacuum case it is that leaving the rod. Since the air passing through the rod is expanding, the exit flow rate is always greater than the entrance flow rate because of this gas expansion. By use of the ideal gas law, a simple correction can be applied as indicated at the bottom of the table to convert entry flow rates into exit flow rates. When this correction is applied, we obtain flow rates as listed in the second column of Table 1 , and virtually identical pressure drops are obtained at a common flow rate as shown at the bottom of the table.

This point is quite important in any pressure drop measurement and is frequently overlooked. We occasionally have disagreements with other laboratories in comparative pressure drop tests, and usually the cause of the disagreement is that the two groups are not measuring flow at the same place in the filter rod or tobacco column. As reported by Gebring (7), the flow leaving the rod has been accepted as a standard condition by ISO/TC126-SC1 and the Coresta Technology Group.

Another point that is evident in Table 1 is that the direction of flow is unimportant in this ordinary acetate tow filter. Identical pressure drops of $364 \mathrm{~mm}$ were obtained at an exit flow rate of $17.5 \mathrm{ml} / \mathrm{s}$ in both the pressure and vacuum measurements in which the flow directions are reversed. This was found to be the case for all the filter rods of differing lengths and deniers, the various lengths of tobacco column and for the series of multicapillaries examined. These of course are symmetrical structures for which this would be expected, and for nonsymmetrical items such as filter cigarettes, ventilated filters, a flow direction dependence can exist.

Table 1. Pressure drop as a function of flow rate $(120 \mathrm{~mm} 3.3$ Y / 44000 cellulose acetate tow).

\begin{tabular}{|c|c|c|c|c|}
\hline \multicolumn{3}{|c|}{ Pressure measurement } & \multicolumn{2}{|c|}{ Vacuum measurement } \\
\hline $\begin{array}{c}\text { Measured } \\
\text { flow (entry) } \\
(\mathrm{ml} / \mathrm{s})\end{array}$ & $\begin{array}{c}\text { Corrected* } \\
\text { flow (exit) } \\
(\mathrm{ml} / \mathrm{s})\end{array}$ & $\begin{array}{c}\text { Pressure } \\
\text { drop } \\
\left(\mathrm{mm} \mathrm{H} \mathrm{H}_{2} \mathrm{O}\right)\end{array}$ & $\begin{array}{c}\text { Measured } \\
\text { flow (exit) } \\
(\mathrm{ml} / \mathrm{s})\end{array}$ & $\begin{array}{c}\text { Pressure } \\
\text { drop } \\
\left(\mathrm{mm} \mathrm{H} \mathrm{H}_{2} \mathrm{O}\right)\end{array}$ \\
\hline 2.7 & 2.7 & 57.7 & 2.8 & 58.8 \\
\hline 5.1 & 5.1 & 107.5 & 5.2 & 108.4 \\
\hline 7.6 & 7.7 & 160.7 & 7.7 & 160.3 \\
\hline 10.0 & 10.2 & 213.5 & 10.1 & 210.5 \\
\hline 13.9 & 14.3 & 296.7 & 14.0 & 291.3 \\
\hline 17.8 & 18.4 & 382.7 & 17.9 & 370.7 \\
\hline 22.4 & 23.4 & 487.3 & 22.4 & 467.3 \\
\hline \multicolumn{3}{|c|}{$\begin{array}{l}\text { pressure drop at } 17.5 \mathrm{ml} / \mathrm{s} \text { measured flow }=378.3 \mathrm{~mm} \mathrm{H}_{2} \mathrm{O} \\
\text { pressure drop at } 17.5 \mathrm{ml} / \mathrm{s} \text { corrected flow }=364.1 \mathrm{~mm} \mathrm{H} \mathrm{H}_{2} \mathrm{O}\end{array}$} & \multicolumn{2}{|c|}{$\begin{array}{l}\text { pressure drop at } 17.5 \mathrm{ml} / \mathrm{s} \\
\text { measured flow }=364.2 \mathrm{~mm} \mathrm{H} \mathrm{H}_{2} \mathrm{O}\end{array}$} \\
\hline
\end{tabular}

$$
\begin{aligned}
& * \text { corrected flow }=\text { measured flow } \times \frac{P_{\text {atm }}+\text { pressure drop }}{P_{\text {atm }}} \\
& P_{\text {atm }}=750 \mathrm{~mm} \mathrm{Hg}=10160 \mathrm{~mm} \mathrm{H}_{2} \mathrm{O} \text { for these experiments }
\end{aligned}
$$


Table 2. Investigation of rod collapsing effects ( $85 \mathrm{~mm}$ tobacco columns).

\begin{tabular}{|c|c|c|c|c|c|}
\hline \multicolumn{2}{|c|}{$\begin{array}{l}\text { Untaped column in rubber sleeve } \\
\text { encapsulator } \\
\text { (vacuum measurement) }\end{array}$} & \multicolumn{2}{|c|}{$\begin{array}{l}\text { Taped column } \\
\text { (vacuum measurement) }\end{array}$} & \multicolumn{2}{|c|}{$\begin{array}{l}\text { Taped column } \\
\text { (pressure measurement) }\end{array}$} \\
\hline $\begin{array}{l}\text { Flow } \\
(\mathrm{ml} / \mathrm{s})\end{array}$ & $\begin{array}{l}\text { Pressure drop } \\
\qquad\left(\mathrm{mm} \mathrm{H}_{2} \mathrm{O}\right)\end{array}$ & $\begin{array}{l}\text { Flow } \\
(\mathrm{ml} / \mathrm{s})\end{array}$ & $\begin{array}{l}\text { Pressure drop } \\
\left(\mathrm{mm} \mathrm{H}_{2} \mathrm{O}\right)\end{array}$ & $\begin{array}{l}\text { Flow } \\
(\mathrm{ml} / \mathrm{s})\end{array}$ & $\begin{array}{l}\text { Pressure drop } \\
\left(\mathrm{mm} \mathrm{H}_{2} \mathrm{O}\right)\end{array}$ \\
\hline \multicolumn{6}{|c|}{ Experimental data: } \\
\hline 2.7 & 10.2 & 2.9 & 11.4 & 2.8 & 11.1 \\
\hline \multirow[t]{2}{*}{6.0} & 24.4 & 5.1 & 20.7 & 5.0 & 20.3 \\
\hline & & 7.6 & 31.8 & 7.5 & 31.5 \\
\hline 10.0 & 42.2 & 10.2 & 43.3 & 10.1 & 43.5 \\
\hline 13.9 & 61.8 & 14.1 & 62.6 & 14.1 & 62.6 \\
\hline 17.4 & 81.4 & 17.8 & 82.4 & 17.8 & 82.9 \\
\hline 22.2 & 108.4 & 22.4 & 107.8 & 22.6 & 109.3 \\
\hline \multicolumn{6}{|c|}{ Calculated from regression equations: } \\
\hline 5.0 & 19.8 & 5.0 & 20.4 & 5.0 & 20.4 \\
\hline 10.0 & 42.3 & 10.0 & 42.9 & 10.0 & 42.9 \\
\hline 15.0 & 67.7 & 15.0 & 67.5 & 15.0 & 67.6 \\
\hline 17.5 & 81.4 & 17.5 & 80.6 & 17.5 & 80.8 \\
\hline 20.0 & 95.8 & 20.0 & 94.3 & 20.0 & 94.6 \\
\hline
\end{tabular}

A further point in Table 1 is the fact that an effect of rod collapse is not apparent in these data. If this were present, the pressure drops under vacuum conditions would tend to be higher than those obtained under pressure conditions because of a reduction in rod diameter in the former case due to collapse under the positive pressure differential between the exterior and interior of the rod. This does not appear to be the case for these rods. To further investigate this point, tobacco columns which would be more susceptible to collapse because of their lower firmness values were measured in several ways. In one experiment, the $85 \mathrm{~mm}$ tobacco column was simply placed in the rubber sleeve encapsulator without additional tape wrapping. In a second, the column was wrapped in tape and only one end was placed in the encapsulator and pressure drops were measured under both pressure and vacuum conditions. The same tobacco columns were used in all three experiments. The data obtained are shown in Table 2. As is apparent in the second part this table, there is relatively little difference between the three sets of measurements, indicating that rod collapse is not a significant factor in this work.

In the measurements reported so far, we have examined pressure drop as a function of exit flow rate which is the recommended procedure for pressure drop measurements (7). However, to investigate the various components of pressure drop, it is better to use an average flow rate, i.e. the flow at the center of the article as this quantity is more easily related to the flows used in theoretical equations. It also has the advantage of requiring the least correction of the observed flows although all observed flows now have to be corrected rather than just those obtained under pressure conditions. Average flow rates are obtained by the following equations: pressure measurements:

$$
\mathrm{Q}_{\mathrm{av}}=\mathrm{Q}_{\mathrm{obs}}\left(1+1 / 2 \frac{\Delta \mathrm{p}_{\mathrm{obs}}}{\mathrm{P}_{\mathrm{atm}}}\right)
$$

vacuum measurements:

$$
\mathrm{Q}_{\mathrm{av}}=\mathrm{Q}_{\mathrm{obs}}\left(1-1 / 2 \frac{\Delta \mathrm{P}_{\mathrm{obs}}}{\mathrm{p}_{\mathrm{atm}}}\right)
$$

where

$Q_{\text {av }}=$ average flow rate $(\mathrm{ml} / \mathrm{s})$,

Qobs $=$ observed flow rate $(\mathrm{ml} / \mathrm{s})$,

$\Delta \mathrm{p}_{\mathrm{obs}}=$ observed pressure drop $\left(\mathrm{mm} \mathrm{H}_{2} \mathrm{O}\right)$,

$\mathrm{p}_{\mathrm{atm}}=$ atmospheric pressure $\left(\mathrm{mm} \mathrm{H}_{2} \mathrm{O}\right)$.

With these average flow rates, multiple regression equations were constructed as listed in Table 3. The 3.3 Y / 44000 filter rods were measured at lengths of 10 , $20,40,60,80,100$ and $120 \mathrm{~mm}$, while the $25 \mathrm{dpf}$ rods were tested at $60,80,100$ and $120 \mathrm{~mm}$ lengths. Tobacco column lengths of $25,45,65$ and $85 \mathrm{~mm}$ were used, and five $120 \mathrm{~mm}$ multicapillary standards ranging in nominal pressure drop between 100 and $643 \mathrm{~mm}$ were also measured. All the regressions closely fit the observed data, with correlation coefficients of 0.999 or better (confidence level $P=0.999+$ ). Deviations of individual measured values from calculated values were generally much less than $2 \mathrm{~mm}$ or $1 \%$ of the measured pressure drops.

As is apparent in the regression equations, some nonlinearity is present in all articles tested. This is illustrated in Figure 2 where the experimental points for a $120 \mathrm{~mm}$ $3.3 \mathrm{Y} / 44000$ tow rod, an $85 \mathrm{~mm}$ tobacco column and 
Figure 2.

Preasure drop as a function of average flow rate.

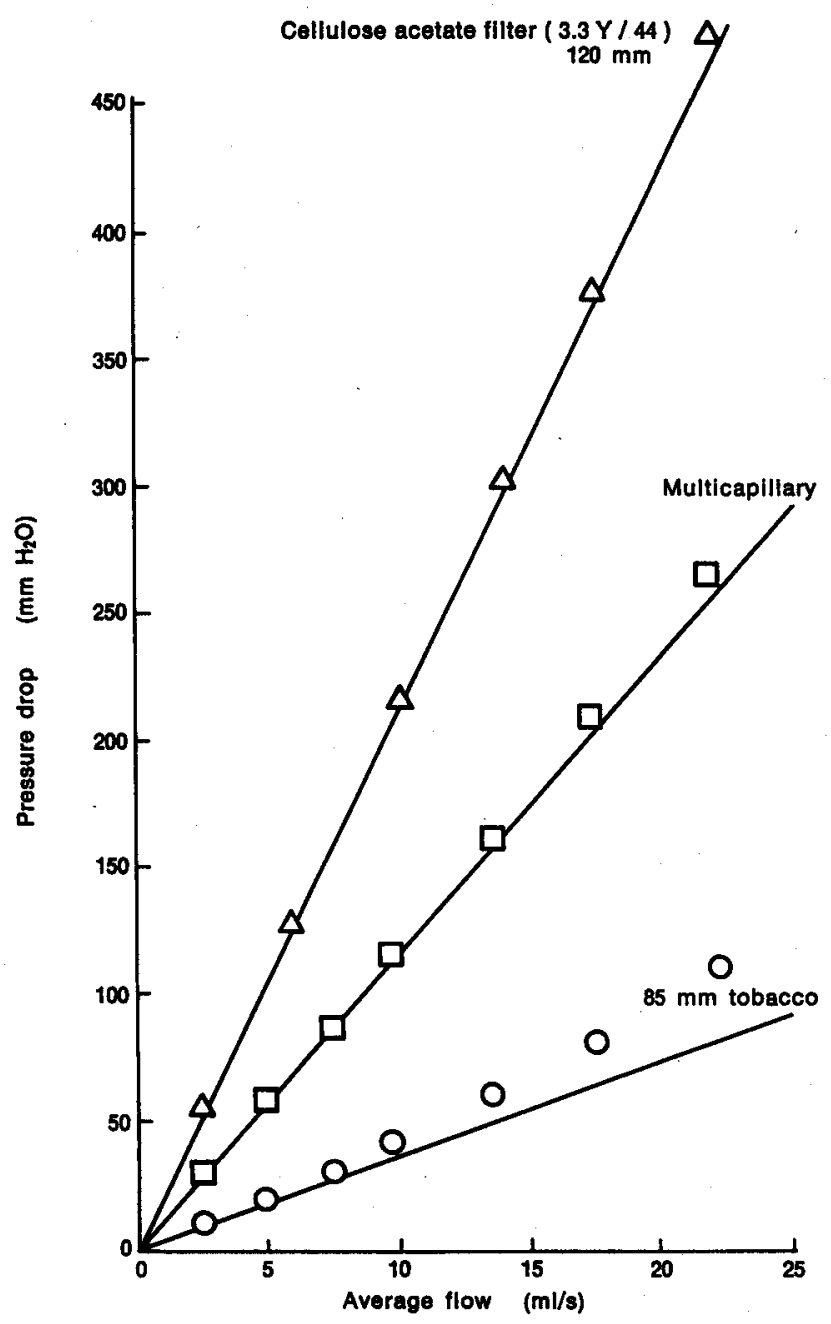

the 208 multicapillary are shown with the linear part of the regression equations forming the respective lines. It is evident for the tow filter and the multicapillary that a viscous flow assumption is quite a good approximation. For tobacco columns the departures from linearity are greater but a viscous flow assumption is still usable in most cases if it is recognized as an approximation.
To further assess the contributions to pressure drop, the regression equations were used to calculate the linear or viscous flow component, the quadratic or entry and exit component, and a length-dependent quadratic term which is presumed to represent the inertial flow contribution. These are listed in Table 4 for the various articles. It should be noted that no subdivision of the multicapillary quadratic term can be made, since only one length of these was available. However, as will be shown later and as found by Keith and Corbin (6) the quadratic term for these is thought to be an entry and exit effect, and hence is independent of length.

In Table 4 it is evident that the constant term is quite small for each article and represents less than $1 \%$ of the overall pressure drop. This small term is thought to arise from experimental errors in the measurements.

The linear term, which represents the viscous or Darcy's Law component of the pressure drop is the major component in the overall pressure drop. It ranges from $78.5 \%$ of the total pressure drop for tobacco columns up to $97.9 \%$ in the case of the normal tow rod.

The quadratic term, which reflects the contribution to pressure drop from the energy expended in funneling air into and out of the article is generally small and relatively constant for the filter rods and tobacco columns, ranging from 1.5 to $1.9 \mathrm{~mm}$. This is a reflection of the relatively low linear velocity in these items which would give low values. In the multicapillary standards, the flow is channeled into and out of ten small capillaries where rather large linear velocities are present. From flow theory, it is expected that these entry and exit corrections should be proportional to the product of the density of the fluid times the linear velocity squared, the proportionality constant being between 0.75 and $1.25(8)$.

Table 5 lists these calculated entry and exit pressure drops and compares them with the quadratic term obtained from regression analysis. It also lists the hole diameters, average linear velocities, and Reynolds numbers for these multicapillaries. The agreement between the values estimated by regression analysis and those calculated from flow theory appears to be quite reasonable, the regression values generally falling in the range of theoretical values. Thus it appears as though the pressure

Table 3. Regression equatlons: Pressure drop $\left(\Delta p, \mathrm{~mm} \mathrm{H}_{2} \mathrm{O}\right)$ v8. average flow rate $(Q, \mathrm{ml} / \mathrm{s})$ and length $(L, \mathrm{~mm})$.

\begin{tabular}{l|l|c|c}
\hline \multicolumn{1}{c|}{ Material } & & $\begin{array}{c}\text { Correlation } \\
\text { coefficient }\end{array}$ & $\begin{array}{c}\text { Data } \\
\text { points }\end{array}$ \\
\hline Tobacco & $\Delta p=0.562+0.0443 \mathrm{LQ}+0.00489 \mathrm{Q}^{2}+0.000610 \mathrm{LQ}^{2}$ & 0.9997 & 56 \\
$3.3 \mathrm{Y} / 44$ tow & $\Delta p=0.489+0.180 \mathrm{LQ}+0.00546 \mathrm{Q}^{2}+0.000165 \mathrm{LQ} \mathrm{Q}^{2}$ & 0.9999 & 42 \\
$25 \mathrm{R} / 50$ tow & $\Delta p=0.377+0.0409 \mathrm{LQ}+0.00606 \mathrm{Q}^{2}+0.000176 \mathrm{LQ} \mathrm{Q}^{2}$ & 0.9999 & 56 \\
100 multicapillary & $\Delta p=0.910+5.40 \mathrm{Q}+0.0185 \mathrm{Q}^{2}$ & 0.9999 & 14 \\
208 multicapillary & $\Delta p=-0.210+11.8 \mathrm{Q}+0.0213 \mathrm{Q}^{2}$ & 0.9999 & 14 \\
380 multicapillary & $\Delta p=-0.201+21.5 \mathrm{Q}+0.0452 \mathrm{Q}^{2}$ & 0.9999 & 14 \\
423 multicapillary & $\Delta p=1.77+23.2 \mathrm{Q}+0.0717 \mathrm{Q}^{2}$ & 0.9999 & 14 \\
643 multicapillary & $\Delta p=0.886+36.3 \mathrm{Q}+0.0881 \mathrm{Q}^{2}$ & 0.9999 & 12 \\
\hline
\end{tabular}


Table 4. Contributions to pressure drop (17.5 ml/s average flow).

\begin{tabular}{|c|c|c|c|c|c|c|c|c|c|}
\hline & $\begin{array}{l}\text { Constant } \\
\left.\text { (mm } \mathrm{H}_{2} \mathrm{O}\right)\end{array}$ & erm & $\begin{array}{r}\text { Linear te } \\
\left(\mathrm{mm} \mathrm{H}_{2} \mathrm{O}\right)\end{array}$ & $\begin{array}{l}\mathrm{rm} \\
(\%)\end{array}$ & $\begin{array}{l}\text { Quadratic } \\
\left(\mathrm{mm} \mathrm{H} \mathrm{H}_{2} \mathrm{O}\right)\end{array}$ & $\begin{array}{l}\text { term } \\
(\%)\end{array}$ & $\begin{array}{l}\text { Length-dep } \\
\text { quadratic } \\
\left(\mathrm{mm} \mathrm{H}_{2} \mathrm{O}\right)\end{array}$ & $\begin{array}{l}\text { Ident } \\
\text { arm } \\
(\%)\end{array}$ & $\begin{array}{c}\text { Total* } \\
\left(\mathrm{mm} \mathrm{H} \mathrm{H}_{2} \mathrm{O}\right)\end{array}$ \\
\hline $85 \mathrm{~mm}$ tobacco & 0.6 & 0.7 & 65.9 & 78.5 & 1.5 & 1.8 & 15.9 & 19.0 & 83.9 \\
\hline $120 \mathrm{~mm} 3.3 \mathrm{Y} / 44$ & -0.5 & 0.1 & 378.8 & 97.9 & 1.7 & 0.4 & 5.9 & 1.5 & 385.9 \\
\hline $120 \mathrm{~mm} 25 \mathrm{R} / 50$ & 0.4 & 0.4 & 85.9 & 90.7 & 1.9 & 2.0 & 6.5 & 6.9 & 94.7 \\
\hline 100 multicapillary & 0.9 & 0.9 & 94.5 & 93.5 & 5.7 & 5.6 & - & - & 101.1 \\
\hline 208 multicapillary & -0.2 & 0.1 & 206.2 & 97.0 & 6.5 & 3.1 & - & - & 212.5 \\
\hline 380 multicapillary & -0.2 & 0.1 & 376.1 & 96.5 & 13.8 & 3.5 & - & - & 389.7 \\
\hline 423 multicapillary & 1.8 & 0.4 & 405.7 & 94.4 & 22.0 & 5.1 & - & - & 429.5 \\
\hline 643 multicapillary & 0.9 & 0.1 & 635.1 & 95.8 & 27.0 & 4.1 & - & - & 663.0 \\
\hline
\end{tabular}

* If. exit flows had been used instead of averege flows, this column would be 83.4, 379.7, 94.1, 100.6, 210.2, 382.3, 420.5 and $642 \mathrm{~mm}$ respectively. The last tive values are in good agreement with the nominal pressure drops of these multicapillarles.

Figure 3. Reynolds number calculation for flbrous beds.

$$
N_{R e}=\frac{e V_{0}}{\mu S}
$$

where:

$$
\begin{aligned}
N_{R_{e}} & =\text { Reynolds number (unitless) } \\
\mathrm{Q} & =\text { fluid specific gravity }(\mathrm{g} / \mathrm{ml}) \\
\mathrm{V}_{0} & =\text { linear velocity, empty tube }(\mathrm{cm} / \mathrm{s}) \\
\mu & =\text { fluid viscosity (poise or } \mathrm{g} / \mathrm{cm} \cdot \mathrm{s}) \\
\mathrm{S} & =\text { particle area per unit volume }(\mathrm{cm}-1)
\end{aligned}
$$

$$
S=\frac{P \alpha}{A}=S_{x} \alpha Q_{f}
$$

where:

$$
\begin{aligned}
P & =\text { fiber perimeter }(\mathrm{cm}) \\
A & =\text { fiber area }\left(\mathrm{cm}^{2}\right) \\
\alpha & =\text { volume fraction occupied by fiber (unitless) } \\
S_{x} & =\text { specific surface area }\left(\mathrm{cm}^{2} / \mathrm{g}\right) \\
\varrho_{f} & =\text { fiber polymer specific gravity }\left(\mathrm{g} / \mathrm{cm}^{3}\right)
\end{aligned}
$$

Thus:

$$
N_{R e}=\frac{\rho A V_{0}}{\mu P \alpha}=\frac{\rho V_{0}}{\mu S_{x} \alpha g_{i}}
$$

drop in multicapillaries results from viscous drag and kinetic entry and exit effects.

In Table 4, the last component of pressure drop is a length-dependent quadratic term which ranges from $5.9 \mathrm{~mm}$ for the lower dpf tow item to $15.9 \mathrm{~mm}$ for a tobacco column. This term represents an inertial flow

\begin{tabular}{|c|c|c|c|c|c|}
\hline $\begin{array}{l}\text { Multicapillary } \\
\text { (nominal } \\
\text { pressure drop, } \\
\text { mm } \mathrm{H}_{2} \mathrm{O} \text { ) }\end{array}$ & $\begin{array}{c}\text { Hole } \\
\text { diameter } \\
(\mathrm{mm})\end{array}$ & $\begin{array}{l}\text { Average } \\
\text { linear } \\
\text { velocity } \\
(\mathrm{cm} / \mathrm{s})\end{array}$ & $\begin{array}{c}\text { Reynolds } \\
\text { number }\end{array}$ & $\begin{array}{l}\text { Expected } \\
\text { cntry and exit } \\
\text { pressure } \\
\text { drop } \\
\left(\mathrm{mm} \mathrm{H}_{2} \mathrm{O}\right)\end{array}$ & $\begin{array}{l}\text { Entry and exit } \\
\text { pressure drop } \\
\text { from regression } \\
\text { analysis } \\
\left(\mathrm{mm} \mathrm{H}_{2} \mathrm{O}\right)\end{array}$ \\
\hline 100 & 0.64 & 544 & 221 & $2.7-4.4$ & 5.7 \\
\hline 208 & 0.52 & 824 & 271 & $6.1-10.1$ & 6.5 \\
\hline 380 & 0.45 & 1100 & 310 & $10.7-17.9$ & 13.8 \\
\hline 423 & 0.44 & 1150 & 316 & $11.7-19.5$ & 22.0 \\
\hline 643 & 0.40 & 1390 & 344 & $16.9-28.2$ & 27.0 \\
\hline
\end{tabular}
contribution to the pressure drop. It is of interest to see whether these contributions are reasonable when com- pared to known information about flow in packed columns. Carman (9) found that inertial flow exists in padked columns at Reynolds numbers of 2 or more. As shown in Figure 3, the Reynolds number in this case is the ratio of the product of fluid density and linear velocity to the product of fluid viscosity and a specific surface area, i.e. the surface area of the particles divided by the volume of the bed. For a fibrous material such as

Table 5. Comparison of entry and exit effects for multicapillarles (ten caplliarles per ltem). 
Table 6. Roynolds numbers and Inertial flow components.

\begin{tabular}{|c|c|c|c|c|c|}
\hline \multirow{2}{*}{ Material } & \multirow{2}{*}{$\begin{array}{c}\text { Perimeter/ } \\
\text { area } \\
\left(\mathrm{cm}^{-1}\right)\end{array}$} & \multirow{2}{*}{$\begin{array}{l}\text { Volume fraction } \\
\text { occupied by } \\
\text { fiber }\end{array}$} & \multirow{2}{*}{$\begin{array}{c}\text { Reynolds } \\
\text { number }\end{array}$} & \multicolumn{2}{|c|}{$\begin{array}{c}\text { Inertial flow } \\
\text { component }\end{array}$} \\
\hline & & & & $\left(\mathrm{mm} \mathrm{H}_{2} \mathrm{O}\right)$ & $(\%)$ \\
\hline $3.3 Y / 44$ & $3540^{\circ}$ & 0.09 & 0.7 & 5.9 & 1.5 \\
\hline $25 \mathrm{R} / 50$ & $1060^{*}$ & 0.10 & 2.1 & 6.5 & 6.8 \\
\hline Tobacco & $192-109^{* *}$ & 0.18 & $6.7-11.8$ & 15.9 & 19.0 \\
\hline
\end{tabular}

- Estlmated from surface areas of 2684 and $808 \mathrm{~cm}^{2} / \mathrm{g}$ respectively (1t).

** Eatimated from shred dimensions of $0.79 \mathrm{~mm}$ width and $0.12-0.24 \mathrm{~mm}$ thickness.

filter rods and tobacco columns, this surface area is equal to the fiber perimeter times the volume fraction occupied by fiber divided by the fiber area. For solid fibers such as acetate this can be estimated from the fiber surface area and the polymer density, while for porous materials such as tobacco, it has to be estimated from the strand dimensions. Table 6 lists the estimated perimeter to area ratios, the volume fraction occupied by fiber and the Reynolds numbers for the two tow items and a tobacco column. It also lists the inertial flow component of the pressure drop from Table 4. It is apparent that the materials with the higher Reynolds numbers have the larger inertial flow components. Tobacco with a Reynolds number well above Carman's (9) criterion of 2 has a sizeable inertial flow component, while the tow items with Reynolds numbers at or below this criterion show relatively little inertial flow. Thus the findings for these articles appear to be consistent with those for packed beds of granular, solid materials.

A final point that should be considered is whether there are appreciable pressure drop contributions from thermal and kinetic effects arising from the expansion of air during its passage through these articles. By use of the integrated forms of Darcy's equation in which density is considered to be a variable for isothermal and adiabatic flow, it is passible to estimate the magnitude of these effects (10). For the 643 multicapillary where these effects would have the greatest magnitude, it is calculated that under isothermal conditions, the gas expansion would contribute $1.5 \mathrm{~mm}$ to the pressure drop. Under thermal expansion conditions up to $0.6 \mathrm{~mm}$ of pressure drop would be obtained by cooling the gas stream by up to $7.4^{\circ} \mathrm{C}$ if a completely adiabatic expansion were achieved - which is unlikely. Since these contributions are only $0.2 \%$ and $0.1 \%$ of the total pressure drop, they can be considered as being negligible in this severest case.

\section{CONCLUSION}

It has been found that the flow regime in cigarette filters, multicapillary pressure drop standards, and tobacco columns is largely laminar or viscous under ordinary conditions. For multicapillary standards a $3.5 \%$ pressure drop contribution arises from channeling air into and out of the article. For cigarette filters there is a small inertial flow and entry and exit flow component of pressure drop. In these tobacco columns, inertial flow is more important, contributing up to $19 \%$ of the pressure drop, while entry and exit effects remain small. Rod collapse and thermal and kinetic effects from gas expansion within the rod were found to be negligible in these. experiments.

\section{SUMMARY}

With a liquid displacement flow system, pressure drop and flow measurements were performed on filter rods, tobacco columns and multicapillary pressure drop standards. The purpose of these measurements was to determine the relative contributions of laminar or viscous flow, inertial flow, and entry and exit effects to pressure drop. Pressure drops were obtained both by forcing and drawing air through the article. No difference in pressure drop was obtained by either method provided that the flow was the same at a common point in the rod. This specification was necessary because of the change in flow rate due to gas expansion inside the rod. Pressure drop contributions from gas expansion, thermal effects and rod collapse were negligible. From regression equations, the major pressure drop component in all three types of article was viscous flow, ranging from $98 \%$ of the total pressure drop in filter rods to $79 \%$ in tobacco columns. Entry and exit effects were small in both filter rods and tobacco columns but were appreciable and the only other pressure drop contributor in multicapillaries. These measured entry and exit effects in multicapillaries agreed well with those estimated by flow theory. Inertial flow was found to contribute $1.5 \%$ and $19 \%$ of the total pressure drop in filter and tobacco rods, respectively. These contributions are reasonable from flow theory for packed columns.

\section{ZUSAMMENFASSUNG}

Druckabfall (Zugwiderstand) und Strömungsvolumen wurden mit einer Flüssigkeitsverdrängungsmethode an Filterstäben, Tabaksträngen und Kapillarenbündeln gemessen. Es sollten die relativen Beiträge von laminarer (viskoser) Strömung, träger Strömung und von Eintrittsbzw. Austrittseffekten zum Druckabfall untersucht wer- 
den. Drudkabfälle über die Proben wurden durch Anlegen sowohl eines Uberdrudkes als auch eines Unterdrukkes erreicht. Unter der Voraussetzung, daß das Strömungsvolumen an einem gemeinsamen Punkt der Probe konstant gehalten wurde, wurden bei beiden Meßmethoden keine Unterschiede gefunden. Dies ist wichtig, da sich das Strömungsvolumen mit der Ausdehnung des Gases im Strang ändert. Druckbeiträge von isothermer und adiabatischer Expansion waren ebenso vernachlässigbar wie das Kollabieren des Stranges unter dem Einfluß der Strömung. Regressionsgleichungen ergaben, da $B$ in allen drei Proben der Hauptbeitrag zum Drudkabfall durch die viskose Strömung gebildet wird. Diese Komponente lag zwischen $98 \%$ beim Filter und $79 \%$ beim Tabakstrang. Eintritts- und Austrittseffekte waren bei Filter und Tabakstrang klein, waren aber merklich bei den Kapillaren. Diese gemessenen Eintritts- und Austrittseffekte stimmten gut mit strömungstheoretischen Abschätzungen überein. Zum Drudkabfall trug der Trägheitseinfluß beim Filter mit 1,5\% und beim Tabakstrang mit 19\% bii. Dieser Beitrag kann durch die Strömungstheorie für gepackte Säulen erklärt werden.

\section{RESUME}

On a procédé a des mesures de résistance au tirage et de débit au moyen d'un dispositif à déplacement de liquide, sur des bâtonnets-filtres, des tronçons de tabac et des étalons à capillaires multiples. Le but de ces expśsiences est de déterminer les parts relatives respectives dues a l'écoulement laminaire, à l'écoulement turbulent et aux effets d'extrémité dans la résistance au tirage. On a opéré à la fois par soufflage et par aspiration à travers l'échantillon. Aucune différence de résistance au tirage n'est décelée entre les deux méthodes, pourvu que le débit mesuré en un point donné de l'éctiantillon soit le même. Il est nécessaire de préciser ceci, compte tenu de la variation de débit en volume provoquée par l'expansion du gaz dans l'échantillon. Les influences sur le tirage dues a l'expansion de l'air, la température et les effets d'extrémité se révèlent négligeables. On établit, à partir des équations de régression, que pour les trois types d'échantillons la part prépondérante est due au flux laminaire, sa contribution variant de $98 \%$ pour les bâtonnetsfiltres à $79 \%$ pour les tronçons de tabac. Les effets d'extrémité sont minimes pour les filtres et les tronçons de tabac, mais sont sensibles pour les étalons multicapillaires où ils constituent la seule autre consid́ration se- condaire. Ces derniers effets sont en concordance avec ceux que la thérie des écoulements permet de calculer. La part due à l'écoulement turbulent est de 1,5\% pour les filtres et de $19 \%$ pour les tronçons de tabac. Ces valeurs sont bien compatibles avec les valeurs theoriques correspondant aux écoulements dans des conduites remplies de matières granuleuses.

\section{REFERENCES}

1. Fordyce, W. B., I. W. Hughes and M. G. Ivinson: The filtration of cigarette smoke; 'Tob. Sci. 5 (1961) $70-75$.

2. Meyer-Abich, K.: Die Strömungsverhältnisse in Cigaretten; Beitr. Tabakforsch. 3 (1966) 307-329.

3. Strydom, M. L., and J. P. Otto: Investigating whether the air flow through cigarettes and filter rods has laminar or turbulent characteristics; Coresta Information Bulletin 1972-2, 13-16.

4. Palmade, P.: Contribution à l'étude des écoulements dans les cigarettes; Annales du Tabac 17/1 (1979) 37-48.

5. Baker, R. R.: Contributions to the draw resistance of a burning cigarette; Beitr. Tabakforsch. 8 (1975) 124-131.

6. Keith, C. H., and J. A. Corbin: Multiple capillary pressure drop standards; Beitr. Tabakforsch. 8 (1975) 60-64.

7. Gehring, M.: Vorschlag für die Definition des Zugwiderstandes; Beitr. Tabakforsch. Int. 9 (1978) 255-261. [cf. Coresta Information Bulletin 1977-1, 17-33.]

8. Chemical Engineers' Handbook (J. H. Perry, editor), p. 388; McGraw-Hill, New York, 1950.

9. Carman, P. C.: Flow of fluids through padked beds; Trans. Inst. Chem. Engrs. (London) 15 (1937) 150153. [cf. Chemical Engineers' Handbook (J. H. Perry, ed.), p. 394; McGraw-Hill, New York, 1950.]

10. Chemical Engineers' Handbook (J. H. Perry, editor), p. 379; McGraw-Hill, New York, 1950.

11. Keith, C. H., and C. F. De Laet: The surface area of fibrous filters; Tob. Sci. 10 (1966) 68-72.

Autbor's address:

Celanese Fibers Company, Researd Department, P.O. Box 32414, Charlotte, N.C., 28232, U.S.A. 